\title{
Instructional Leadership Effects on Teachers' Work Engagement: Roles of School Culture, Empowerment, and Job Characteristics
}

Adel Zahed-Babelan ${ }^{1}$, Ghodratollah Koulaei ${ }^{\star 2}$, Mahdi Moeinikia ${ }^{1}$ AND Ali Rezaei Sharif ${ }^{1}$

$\approx$ In the article, the relations between the principal's instructional leadership, school culture, psychological empowerment, job characteristics, and teachers' work engagement was examined on a sample of 310 elementary school teachers. The results showed no direct effects of the principal's instructional leadership on work engagement; however, they proved the belief that the principal could have an indirect effect on teachers' work engagement through indirect variables: school culture, teacher empowerment, and job characteristics. The research method is structural equation modelling, for the purpose of which five research tools (the Principal Instructional Management Rating Scale, the School Culture Survey, the Job Diagnostic Survey, the Psychological Empowerment Questionnaire, and the Job Engagement Questionnaire) were used for data collection. The participants were selected through a stratified sampling method. The reliability was assessed by Cronbach's alpha. The results showed that the model fitted the data and that the relationship between instructional leadership and job engagement was established entirely through school culture, empowerment, and the job characteristics of teachers. The principals are recommended to apply the instructional leadership approach. By assisting teachers in collaboration, instilling collective leadership, and communicating a shared vision, the principals can contribute to developing a positive and participatory school culture.

Keywords: instructional leadership, work engagement, school culture, empowerment, job characteristics of Mohaghegh Ardabili, Ardabil, Iran; gkoulaei@gmail.com. 


\section{Učinek določitve učnega načrta in usmerjanja pouka, ki ga izvaja ravnatelj, na delo učiteljev: pomen šolske kulture, opolnomočenja in značilnosti poklica}

Adel Zahed-Babelan, Ghodratollah Koulaei, Mahdi Moeinikia in Ali Rezaei Sharif

V V članku smo na vzorcu 310 osnovnošolskih učiteljev preučili odnose med ravnateljem, ki določi učni načrt in usmerja pouk, šolsko kulturo, psihološkim opolnomočenjem, značilnostmi poklica in delovno angažiranostjo učiteljev. Izsledki niso pokazali neposrednih učinkov ravnateljevega usmerjanja na delovno vnemo, vendar so podprli prepričanje, da bi lahko ravnatelj posredno vplival na delo učiteljev prek posrednih spremenljivk: šolske kulture, opolnomočenja učiteljev in značilnosti poklica. Metoda raziskave je modeliranje strukturnih enačb, pri čemer smo uporabili pet raziskovalnih orodij za zbiranje podatkov: ocenjevalno lestvico usmerjanja pouka, ki ga je izvajal ravnatelj, anketo o šolski kulturi, anketo o poklicni diagnostiki, vprašalnik o psihološkem opolnomočenju, in vprašalnik o poklicnem udejstvovanju. Preiskovanci so bili izbrani z metodo stratificiranega vzorčenja. Zanesljivost je bila ocenjena s Cronbachovo alfo. Izsledki so pokazali, da model ustreza podatkom ter da je bilo razmerje med ravnateljevim usmerjanjem pouka in zaposlovanjem v celoti ugotovljeno s šolsko kulturo, $\mathrm{z}$ opolnomočenjem in s poklicnimi značilnostmi učiteljev. Ravnateljem se predlaga, da uporabijo pristop, $\mathrm{v}$ katerem določijo učni načrt in usmerjajo pouk. Ti lahko prispevajo $\mathrm{k}$ razvoju pozitivne in sodelovalne šolske kulture, in sicer tako, da pomagajo učiteljem pri njihovem medsebojnem sodelovanju, da vzbudijo kolektivno vodenje in sporočijo skupno vizijo.

Ključne besede: določitev učnega načrta in usmerjanje pouka, delovna vnema, šolska kultura, opolnomočenje, značilnosti poklica 


\section{Introduction}

Leadership is one of the most studied topics in the organisation sciences, and employee engagement one of the more recent. However, the relationship between leadership and employee engagement has not been widely investigated. As many organisations invest significant resources in retaining, developing, and engaging employees, human resource development (HRD) professionals are tasked to develop and partner with leaders to deliver those strategies effectively. Thus, a comprehensive understanding of the relationship and mechanism between leadership and engagement is essential in order to inform leaders on how best to cultivate positive results in followers (Carasco-Saul, 2014; Kim \& Kim, 2014).

Leadership has increasingly been perceived as a critical factor in organisational as well as school effectiveness. The increased interest in instructional leadership evidenced over recent decades is due to the trend of continuous reforms of education systems throughout the world. These changes have led to a dramatic growth in the importance of the role assigned to school leaders, both individually and collectively (Hallinger \& Huber, 2012). According to Hallinger and Heck (1996), studies yielded frequent instances of positive findings concerning the role of the principal in school effectiveness.

Work engagement is a matter of concern for leaders and managers in organisations across the globe; they recognise it as a vital element affecting organisational effectiveness (Welch, 2011). Work engagement is defined as a positive, fulfilling, work-related state of mind that is characterised by vigour, dedication, and absorption (Schaufeli et al., 2002). Employee engagement concerns the degree to which individuals make full use of their cognitive, emotional, and physical resources to perform role-related work. Thus, employees who are engaged in their work have energetic, enjoyable, and effective connections with their work (Xu \& Thomas, 2011). They state that leadership is a crucial antecedent to engagement. Leadership research shows that certain leadership behaviours have a clear association with engagement. Trust in the leader, support from the leader, and creating a blame-free environment are considered to be components of psychological safety, a condition proposed by Kahn, which leads to employee engagement. However, few studies have attempted to provide evidence of association between leadership and employee engagement (Bedarkar \& Pandita, 2014), In other words, a gap remains in understanding what leadership behaviours could affect engagement-encouraging cultures as well as the processes around which leader behaviours bring about higher levels of engagement, which is in line with the more drastic argument that there is no research directly linking leaders' behaviours and follower engagement $(\mathrm{Xu} \&$ 
Thomas, 2011). By examining current literature that studied the relationship between leadership and employee engagement, we have attempted to fill the knowledge gap while offering a comprehensive understanding of that relationship to leaders in organisations.

The task of unravelling the effects of instructional leadership on teacher engagement has been complicated by the concurrent effects of three related but separately measured constructs: school culture, teacher empowerment, and their job characteristics.

In the 1980s, when instructional leadership emerged as a new construct, some scholars questioned both its relevance and viability as a guiding metaphor for school leadership. Thirty years later, 'instructional leadership' and 'leadership for learning' are widely accepted by policymakers and practitioners as essential elements of management practice in schools. Indeed, recent reviews of research largely confirm early assertions concerning the relationship between instructional leadership and student learning. Thus, contrary to early predictions, instructional leadership has demonstrated impressive staying power as a core concept guiding both practices in the field of educational leadership and management (Hallinger, 2010).

The dynamic processes of culture creation and management are the essence of leadership and lead one to understand that leadership and culture are two sides of the same coin (Schine, 2004). School culture is commonly used to describe the unique working conditions inside organisations and to distinguish one school from another. Organisational culture represents a broad umbrella, referring to the traditions, rituals, shared norms, and assumptions of a school. These site-specific beliefs are adopted over time and provide a distinct character to the school. Educational theorists have reported that the principals' impact on learning is mediated through the culture of the school and is not a direct effect (Hallinger \& Heck, 1998). There is substantial evidence in the literature to suggest that a school principal must first understand the school's culture before implementing change. Bulach (2001) stated that a leader must identify a school's existing culture before attempting to change it. Leonard (1999) studied the dynamics and complexities of a school culture when teacher values were compatible or in conflict with school culture, with predictable results. Mortimore (2001) warned that we should concentrate on establishing more knowledge about the complex interactions between culture and schooling. Lakomski (2001) studied the claim that it is necessary to change an organisation's culture to bring about organisational change and concluded that there is a causal relationship between the role of the leader and organisational learning. Leaders use culture to shape employee engagement (Gordon, 2013). A collaborative culture 
is the foundation upon which a professional learning community rests. Such a culture is an essential ingredient for long-term, continuous school improvement (Deal \& Peterson, 1999). Collaborative school cultures have been presented as the best setting for learning for both teachers and students. School leaders that shape their cultures to become more collaborative should reap the benefits of greater teacher performance and satisfaction. Many authors have written about school culture. For this study, 'culture' is defined as the guiding beliefs, assumptions, and expectations that are evident in the way a school operates (Gruenert, 2005). Successful school principals comprehend the critical role that the organisational culture plays in developing a successful school (MacNeil et al., 2009). School cultures are categorised as either positive, toxic or anywhere in between. Core values within the school often play an essential role in determining the type of culture one will find in a school. A positive school culture is the result of many influences. Schools should be focused on creating a learning community for all involved. All individuals should have a sense of caring and respect for each other. Staff and students need to be positive about their ability to set and achieve ambitious goals. Positive attitudes go a long way in developing and maintaining a positive culture. As instructional leaders, principals can create a positive and collaborative school culture. By helping teachers collaborate, instilling collective leadership, and communicating a shared vision, principals can contribute to developing a positive and collaborative school culture. Principals may consider providing teachers with frequent common planning and team time, and an atmosphere of lifelong learning and trusting relationships in order to establish a positive and collaborative school culture. People in toxic cultures tend to concentrate on negative values. Classrooms often become isolated with no deeper bond to bring them together. People become fragmented in other ways. The result is that the school lacks a shared vision. People then feel lost and become negative about their situation. The whole culture becomes dysfunctional (DuPont, 2009). Healthy school cultures can ' [...] lead to enhanced commitment and performance that are beyond expectations. As a result, the school is better able to achieve its goals (Sergiovanni, 2006).

There are many different ways to assess school culture with none being perfect. Steven Gruenert (1998) developed The School Culture Survey. Gruenert argues that researchers need to use both quantitative and qualitative assessments to measure organisational culture. The researchers use The School Culture Survey combined with qualitative methods the researcher will gain the necessary insights to describe a culture.

Employee empowerment has been recognised as an essential contributor to organisational success. Empowering employees is essential for organisations 
to react quickly to changes in the environment. Psychologically empowered employees positively influence individual and organisational outcomes. Psychological empowerment is positively associated with engagement and commitment. Jose and Mampilly (2014) showed that 71.7 per cent of the variation in employee engagement is explained by the four dimensions of psychological empowerment together. Psychological empowerment is defined as a motivational concept composed of four dimensions: meaning, choice, competence, and impact. Meaning corresponds to the value employees assign to their job according to their beliefs and standards. It is the fit between the requirements of a task or work goal and personal values or ideas. Meaning in work is seen as a method of fostering employees' motivation and attachment to work, thus resulting in engagement. Choice refers to the degree to which an individual perceives that he can initiate and regulate his actions. The core element of this concept is the feeling of self-determination. Workers feel responsible for their outcomes if they experience autonomy to make decisions regarding their tasks. According to the Job Demands Resources model of work engagement, job resources such as autonomy start a motivational process that leads to work engagement. Competence is defined as the employees' beliefs in their capability to perform their tasks skilfully. It refers to the perception that one has the required abilities to cope with different work situations (Spreitzer, 2007). Competence derives from the concept of self-efficacy, which promotes initiative, persistence, and greater effort to deal with difficult situations (Bandura, 1969). Finally, impact corresponds to the perception that employees' behaviours may influence results at work. It is the degree to which employees feel that they can make a difference through their behaviours in order to accomplish their task goals that contributes to employee engagement (Quiñones, Van den Broeck, \& De Witte, 2013). Rinehart, Short, Short, and Eckly (1998) found that empowerment can be traced to the relationship between principals and teachers. If the thrust of reform is to shift decision making to those closest to the core, then teacher empowerment is an essential issue; and the association between principals and teachers becomes paramount. Therefore, principals should develop persuasive attributes of pursuing similar goals. School leaders may enable the empowerment of teachers and teams by frequently expressing their genuine belief that teachers care about the goals of the school, are competent to make good decisions in areas of major concern and are presumptively honest in their intentions (Dee, Henkin, \& Duemer, 2003).

Teacher empowerment is increasingly gaining attention among scholars and practitioners across educational contexts due to its positive associations with a number of teachers' work-related outcomes. A basic assumption of 
teacher empowerment is that teachers are autonomous professionals who are willing to perform their best at work when they feel intrinsically motivated and satisfied. Accordingly, advocates see an imperative need for school leaders to adopt a more empowering management approach to facilitate teacher empowerment effectively. However, the relationship between psychological processes of empowerment, particularly in terms of school leaders' empowering behaviours and teachers' psychological empowerment remains largely underexplored according to Lee and Nie (2014). They found that principals' perceived empowering behaviours were not directly associated with teachers' job satisfaction but teachers' work motivation (i.e., meaningfulness, competence, choice and impact) was positively associated with teachers' job satisfaction. They speculated that the principals' perceived empowering behaviours might be indirectly associated with teachers' job satisfaction through teachers' work motivation.

Despite limited empirical research on teachers' psychological empowerment as a mediating variable, many recent studies in the non-educational work contexts have reported that employees' psychological empowerment mediated the relationship between leaders' empowering behaviours and employees' work outcomes such as job satisfaction.

Research suggests that followers are paying more attention to concepts such as meaningful work, authenticity, and social responsibility. Thus, the leaders need to be prepared with new perspectives, visions, and models that equip them to meet the challenges of an evolving organisational landscape (Shuck \& Herd, 2012). Management and leadership play a significant role in employee engagement, but it is equally important for employees to have enthusiasm for the work that they do. Beyond mastering the job's tasks, employees need to feel pride in what is being accomplished and share in the excitement when goals are achieved. The more employees feel they are building their own skill sets and feel competent and in control of their work product, the more likely they are to demonstrate high levels of engagement (Wiley, 2010). According to the job characteristic theory, having new tasks incorporated into an employee's daily work changes the 'core job characteristics' of that work. This model provides employees with more experienced meaningfulness, more experienced responsibility, and greater knowledge of the fruits of their labours - three psychological states that motivate employees and increase their job satisfaction. When administrators trust faculty with decisions dealing with issues of teaching and learning, time, teachers' voices will eventually be heard in the spheres of administrative decisions. Eventually, the principal's influence will expand too, into the spheres of teaching and learning. This form of work redesign will flatten the organisational hierarchy as both groups share their traditional spheres of work. 
Thus, it is suggested that administrators experiment with redesign reforms that redefine the nature of teachers' work (Mayrowetz \& Smylie, 2004). Therefore, one of the fundamental ways in which leaders influence followers is by creating meaningful work. Testing this notion, we linked leadership behaviours to employees' perceptions of their jobs (e.g., the significance, meaningfulness, and importance of the work). Salancik and Pfeffer (1978) argued that characteristics of a job or a task are 'not given but constructed'. In other words, employees use information from their social context (such as social norms and expectations) to make judgments and develop perceptions of the 'meaningfulness, importance, and variety of the job'. Salancik and Pfeffer further specified that supervisors are a potent source of social information and that they can affect employees' attitudes about their jobs and tasks to a considerable extent.

Based on the review of the literature, the hypothesised conceptual model that guided this study is displayed in Figure 1. In this model, leadership is viewed solely as an independent variable. Therefore, principals are hypothesised as shaping a variety of processes that indirectly influence teachers. Understanding the routes by which principals can improve school outcomes is a worthy goal for this research.

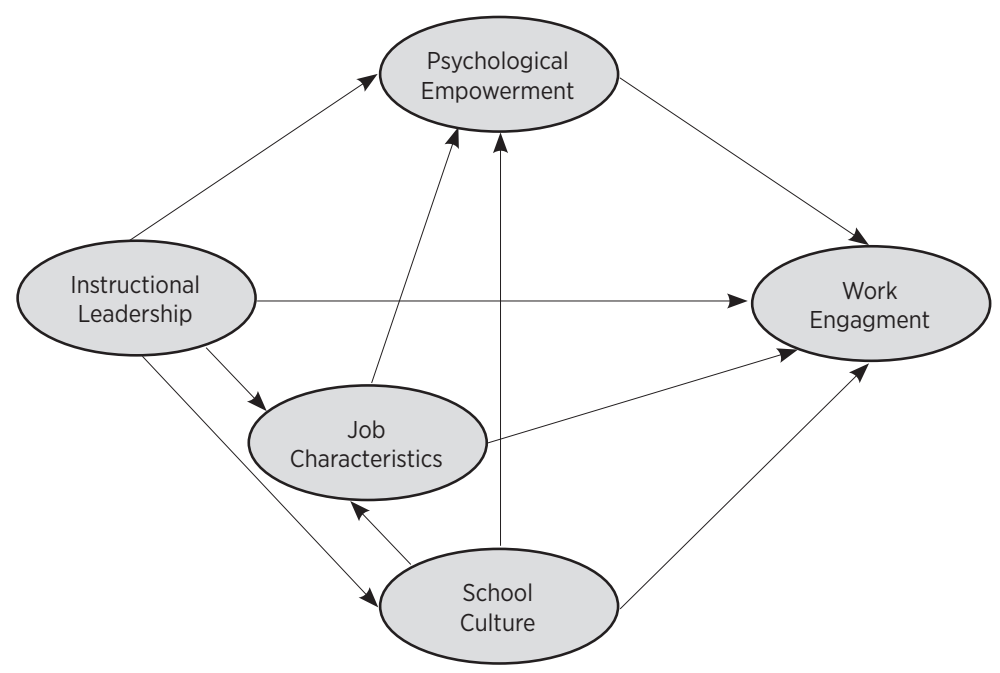

Figure 1. Theoretical framework.

Based on the model the following hypotheses have been formulated:

- $\quad H 1$ : Instructional leadership is positively related to work engagement.

- $\quad$ H2: Instructional leadership is positively related to school culture.

- H3: Instructional leadership is positively related to job characteristics. 
- H4: Instructional leadership is positively related to psychological empowerment.

- H5: Instructional leadership affects psychological empowerment indirectly via school culture and job characteristics.

- H6: Instructional leadership affects job characteristics indirectly via school culture.

- H7: Instructional leadership affects work engagement indirectly via school culture, psychological empowerment and job characteristics.

- H8: School culture affects psychological empowerment indirectly via job characteristics.

- H9: School culture affects work engagement indirectly via psychological empowerment and job characteristics.

- H10: Job characteristics affect work engagement indirectly via psychological empowerment.

\section{Method}

\section{Data collection}

To achieve the objectives of the study, we used structural modelling to test the fit of the conceptualisations that model principals' instructional leadership effects on teachers' engagement.

The study utilised a five-part questionnaire, which contained a series of questions to which participants responded by indicating their level of agreement/disagreement on a five-point scale ranging from strongly agree (score $=5$ ) to strongly disagree (score $=1$ ). Data were collected on the following measures.

Principal instructional leadership was measured using a 22-item scale derived from a short version of the PIMRS ${ }^{3}$ Teacher Form Scale measuring the three dimensions (i.e., Defines the School Mission, Manages the Instructional Programme, Develops a Positive School Learning Climate) (Hallinger \& Wang, 2015).

School Culture Survey (SCS), a six-factor, 35-item survey was completed by teachers about their school's culture. The factors are (1) Collaborative Leadership, (2) Teacher Collaboration, (3) Professional Development, (4) Collegial Support, (5) Unity of Purpose, and (6) Learning Partnership.

The Empowerment Scale. Spreitzer's (1992) multidimensional measure of empowerment is a self-report scale that includes four types of feelings: (a) autonomy, defined as a sense of freedom in making choices about how to

3 Principal instructional management rating scale. 
do one's work, and the resulting feelings of personal responsibility for these choices; (b) competence, defined as the belief in one's ability to perform a job successfully; (c) meaningfulness, defined as the perceived value of one's job in relation to one's personal beliefs, attitudes, and values; and (d) impact, defined as the belief that one is producing intended effects and has control over desired outcomes through one's task behaviour (Spreitzer, 1992).

The Job Diagnostic Survey. Employees' perceptions of their jobs were assessed using a 23-item version of the Job Diagnostic Survey (Hackman \& Oldham, 1980). Employees responded to statements about their job on a scale ranging from 1 (very inaccurate) to 5 (very accurate).

Employee Engagement. To measure employee engagement, the short form of the Utrecht Work Engagement Scale (UWES) was used (Schaufeli et al., 2006). The UWES includes three dimensions of engagement (vigour (3 items), dedication ( 3 items), and absorption ( 3 items)) to comprise a nine-item measure. The items are presented as descriptive statements, and respondents indicate the frequency with which each statement applies on a five-point scale.

\section{Participants and data analysis}

The statistical population of the study consisted of 1,606 teachers, working in 168 elementary schools. The sample size was determined based on Krejcie and Morgan's formula (1970), which consisted of 310 participants selected via a proportional stratified random sampling approach. Participants of the current study were a random sample of male and female elementary teachers in the northwest of Iran (West Azerbaijan Province), working in an urban teaching district. Of the subjects, there were 289 females and 21 males. The mean ages of the subjects were 36.11 (women), and 34.55 (men) years; $6 \%$ of respondents did not mention their age. They were of two educational levels: Bachelor $(\mathrm{N}=266)$ and Master $(\mathrm{n}=29) ; 5 \%$ did not state their educational level. According to Noora (2008), the culture of teaching in Iran is primarily teacher-centred, and the curriculum in schools is a top-down curriculum; the Ministry of Education dictates all the decisions regarding textbook selection and the exams. However, not much control is exerted on teaching methodology. The results of the exams are not determined by numerical scores but use the terms 'excellent', 'good', 'satisfactory' and 'needs further improvement'. Most teachers are strict about setting lots of supplementary books for students to work on preparation for exams, in addition to the books they study at school.

We tested the model using structural modelling software, LISREL 8.8. Structural modelling, a form of path analysis, allows the testing of assumptions 
of causality in relationships among multiple variables within a model. It fits the need in this study to understand relationships among multiple interrelated variables.

\section{Results}

Even though all measurement scales were validated in previous studies, it was necessary to ensure the reliability and validity of the measurement scales in this study. To do this, this study assessed the internal consistency of each construct measurement scale by Cronbach's alpha coefficient estimates and examined interconstructs' convergent reliability by interconstruct correlation coefficient estimates. The resulting findings are shown in Table 1.

Table 1

Reliability Estimates

\begin{tabular}{|c|c|c|c|c|}
\hline \multicolumn{3}{|c|}{$\alpha$ for whole items of each instrument } & \multicolumn{2}{|l|}{$\alpha$ for sub-dimensions of each instrument } \\
\hline \multirow{3}{*}{ Instructional Leadership } & \multirow{3}{*}{22 items } & \multirow{3}{*}{.96} & Defining the School Mission & .88 \\
\hline & & & Managing the Instructional Programme & .92 \\
\hline & & & Developing a Positive School Learning Climate & .91 \\
\hline \multirow{6}{*}{ School Culture } & \multirow{6}{*}{35 items } & \multirow{6}{*}{.97} & Collaborative Leadership & .92 \\
\hline & & & Collegial Support & .78 \\
\hline & & & Learning Partnership & .79 \\
\hline & & & Professional Development & .83 \\
\hline & & & Teacher Collaboration & .82 \\
\hline & & & Unity of Purpose & .84 \\
\hline \multirow{4}{*}{ Empowerment } & \multirow{4}{*}{12 items } & \multirow{4}{*}{.94} & Competence & .81 \\
\hline & & & Autonomy & .87 \\
\hline & & & Impact & ,86 \\
\hline & & & Meaningfulness & .74 \\
\hline \multirow{5}{*}{ Job Characteristics } & \multirow{5}{*}{23 items } & \multirow{5}{*}{.91} & Skill Variety & .68 \\
\hline & & & Task Identity & .74 \\
\hline & & & Task Significance & .71 \\
\hline & & & Autonomy & .68 \\
\hline & & & Feedback & .65 \\
\hline \multirow{3}{*}{ Work Engagement } & \multirow{3}{*}{9 items } & \multirow{3}{*}{.95} & Vigour & .82 \\
\hline & & & Dedication & .90 \\
\hline & & & Absorption & .93 \\
\hline
\end{tabular}


As shown in Table 1, the internal consistency reliabilities for all of the constructs exceeded Nunally's (1978) required level of .70 (from $\alpha=.91$ to $\alpha$ $=.97$ ). Thus, the measures tended to be reliable in the context. Additionally, this study also assessed the internal consistency for each sub-dimension of the measurements. (Coefficient alpha ranges from .65 to .93). Furthermore, correlation analysis indicated acceptable inter-correlations among the latent variables at the $\mathrm{p}=0.01$ level, as shown in Table 2

Table 2

Correlation Matrix of ETA and KSI

\begin{tabular}{lcccccc}
\hline Variable & Mean & $\mathbf{2}$ & $\mathbf{3}$ & $\mathbf{4}$ & $\mathbf{5}$ & $\mathbf{1}$ \\
\hline 2) School Culture & 137.56 & 1.00 & & & & \\
3) Psychological Empowerment & 45.92 & .93 & 1.00 & & & \\
4) Job Characteristics & 90.26 & .77 & .79 & 1.00 & & \\
5) Work Engagement & 35.33 & .95 & .98 & .79 & 1.00 & \\
1) Instructional leadership & 86.23 & .90 & .89 & .74 & .89 & 1.00 \\
\hline
\end{tabular}

\section{Testing the structural model}

The structural relationships among five variables were tested by structural equation modelling (SEM) using the Lisrel 8.8 statistical package. SEM allows researchers to examine measurement errors and both direct and indirect structural relationships among variables. As shown in Table 3, the hypothesised model provided an overall adequate fit to the data.

Table 3

Model Fit Indices for Hypothesised Model

\begin{tabular}{lccccccccc}
\hline Model Fit Indices & $\chi^{2}$ & $\chi^{2} / \mathrm{df}$ & RMSEA & SRMR & RMR & GFI & AGFI & CFI & NFI \\
\hline Hypothesised Model & 381.65 & 2.12 & .067 & .027 & .42 & .87 & .84 & .99 & .99 \\
\hline
\end{tabular}

As depicted in Figure 2 and with regard to the measurement part of the structural model, all factor loadings of the constructs for each latent variable are greater than .50 (Hair et al., 2006), indicating statistical significance (factor loadings ranged from .79 to .96). The effect size of the paths was determined by standardised path coefficient (SPC), which represents standardised regression coefficients that measure the effect of one variable on other variables. The significance of SPC is determined by a t-value, and when that value is higher than 1.96 (Kline, 2011), SPC estimates are statistically significant. They are depicted near the lines 
in Figure 2. The results showed that most of the hypothesised structural relationships among the five latent variables were statistically supported.

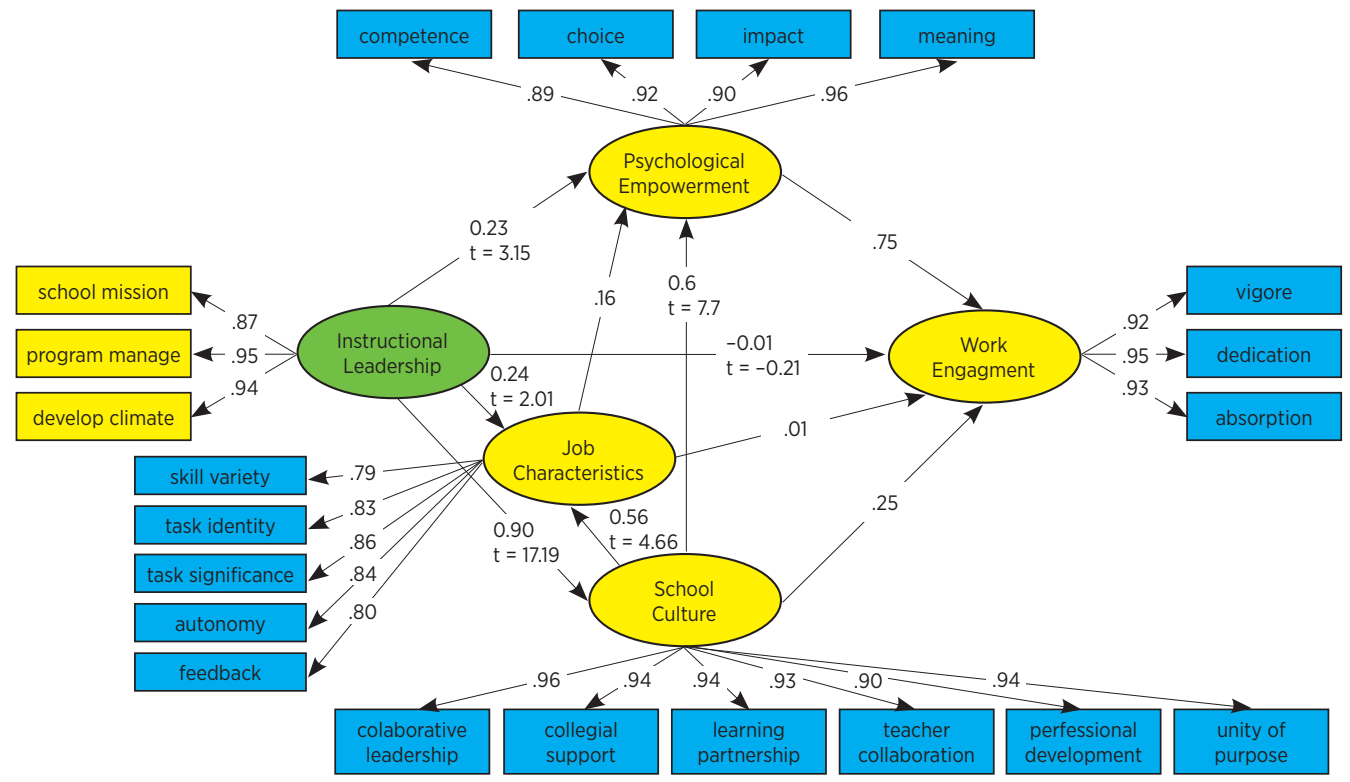

Figure 2. Standardised solution.

The results showed that instructional leadership had a positive, direct and statistically significant influence on school culture $\left(\mathrm{H}_{2}\right)$, job characteristics $\left(\mathrm{H}_{3}\right)$, and psychological empowerment $\left(\mathrm{H}_{4}\right)$ but not on work engagement $\left(\mathrm{H}_{1}\right)$.

The Correlation Matrix of latent variables is illustrated in Table 1.

This study developed six other hypotheses to examine the mediating role of school culture, job characteristics, and psychological empowerment. As shown in Figure 2 and Table 4, to further explain the influential relationships among latent variables, instructional leadership affected psychological empowerment indirectly via school culture and job characteristics $\left(\mathrm{H}_{5}\right)$, on job characteristics indirectly via school culture (H6), and on work engagement indirectly via school culture, psychological empowerment and job characteristics ( $\mathrm{H}_{7}$ as the main hypothesis of the study). In addition, school culture affects psychological empowerment indirectly via job characteristics (H8) and work engagement indirectly via psychological empowerment and job characteristics ( $\left.\mathrm{H}_{9}\right)$. Finally, job characteristics affect work engagement indirectly via psychological empowerment ( $\mathrm{H}_{10} \mathrm{O}$.

Additionally, this study examined SEM direct and indirect standardised path coefficients to further explain the influential relationships among latent 
variables. According to the results of the hypothesised model in Table 4 and Figure 2, the study hypotheses were examined as follows:

Instructional leadership had the total effect of .90 on school culture; of .89 on psychological empowerment, of which .66 was transmitted via school culture and job characteristics; of .74 on job characteristics, of which .50 was transmitted via school culture and of .89 on work engagement, of which .90 was transmitted via school culture, job characteristics and psychological empowerment. School culture had the total effect of .69 on psychological empowerment, of which 0.09 was transmitted via job characteristics; of .69 on .56 on job characteristics and of .78 on work engagement, of which .52 was transmitted via job characteristics and psychological empowerment. Psychological empowerment had the total effect of .75 on work engagement. Job Characteristics had the total effect of .16 on psychological empowerment and of .13 on work engagement, of which .12 was transmitted via psychological empowerment.

Table 4

Standardised coefficients of direct, indirect and total effects

\begin{tabular}{lccc}
\hline Path & Direct effect & Indirect effect & Total effect \\
\hline Leadership $\rightarrow$ Culture & .9 & 0 & .9 \\
Leadership $\rightarrow$ Empowerment & .23 & .66 & .89 \\
Leadership $\rightarrow$ Job Characteristics & .24 & .50 & .74 \\
Leadership $\rightarrow$ Engagement & -.01 & .90 & .89 \\
Culture $\rightarrow$ Empowerment & .60 & .09 & .69 \\
Culture $\rightarrow$ Job Characteristics & .56 & 0 & .56 \\
Culture $\rightarrow$ Engagement & .26 & .52 & .78 \\
Empowerment $\rightarrow$ Engagement & .75 & 0 & .75 \\
Job Characteristics $\rightarrow$ Empowerment & .16 & 0 & .16 \\
Job Characteristics $\rightarrow$ Engagement & .01 & .12 & .13 \\
\hline
\end{tabular}

\section{Conclusions}

The analysis of results identified that instructional leadership had a positive association with work engagement although the direct relation between them was non-significant in the model and the first hypothesis was not supported, but the total effect is completely due to mediating variables indicating their full role between the two. This finding is analogous to the results of Pavlova (2013) who suggested this interesting result because of some probable gap between employees and leadership. 
The next result is the positive association of instructional leadership and school culture. This result confirms previous studies (e.g., Le Clear, 2005; Peterson \& Deal, 2009; Schine, 2004; Valentine, 2006) that found that leadership and culture are two sides of the same coin and that having a collaborative school culture is necessary for effective performance, and that the stronger the culture, the more effective the organisation. To develop a meaningful and productive school, leaders must shape a culture in which every teacher can make a difference, and every child can learn and in which there is a passion for, and commitment to promoting the best is possible. However, as Iran has a relatively high power-distance culture (Dastmalchian et al., 2001) and schools do not wish to change quickly, the principal's role is inherently conservative and emphasises managerial rather than leadership behaviour. Principals have always been agents of stability rather than agents of change. Nevertheless, the current era poses new challenges for school principals and creates a new cultural context for education and schools. Educational systems implementing reforms need to be moderated by the will and skill of school principals. This has resulted in a new interest in changing school principals from agents of stability into leaders of change. Therefore, principals need to work harder at articulating the basis of reform and at creating interest among teachers in engaging in education.

The association between instructional leadership and core job characteristics is consistent with other findings (Gagné et al., 1997; Piccolo et al., 2012; Piccolo \& Colquitt, 2006; Purvanova et al., 2006). One of the more powerful influences a leader can have on followers is in the 'management of meaning' as leaders define and shape the 'reality' in which followers work. According to Piccolo and Colquitt (2006), leaders could influence perceived core characteristic levels by changing the language, imagery, and symbols used to communicate meaning on the job.

We also found a positive link between leadership and empowerment, which is consistent with previous findings (Maxfield \& Flumerfelt, 2009; Rinehart et al., 1998). Since managers are mostly characterised as being the decision makers, empowerment strategies need to start where the power lies, at the top. Given the increasing complexity of the global environment, it is no longer conceivable for managers to be the source of all knowledge; therefore, managers need to consult and involve workers in the decision-making process as opposed to merely expecting worker compliance.

Thomas and Velthouse (1990) suggested changing the environment to enhance empowerment. The job characteristics studied here are one instance of this type of change. In this vein, Hackman and Oldham (1975) proposed concrete interventions intended to increase the levels of desirable job 
characteristics. The present study demonstrated that the dimensions of empowerment can be affected by job characteristics.

The result shows the role of school culture in increasing teachers' psychological empowerment. School culture which is based on open communication and flexibility allows teachers to participate in decision making and express their opinions and support feedback.

Finally, increased leadership empowerment behaviour will result in higher levels of psychological empowerment, which, in turn, will increase work engagement. When leaders thus increase employees' degree of authority, decision-making and accountability, share information and support, develop and coach employees for innovative performance, employees will experience feelings of control. When individuals feel that their inputs are valued and that they make a meaningful contribution to the business strategy (impact), they will feel more engaged.

\section{Practical Implications, Limitations and future directions of research}

Our results have significant practical implications:

- Leadership training courses could be developed to teach leaders how to create meaning for jobs that may on the surface appear to be less important or significant. This can be done by linking jobs to the broader purpose, goals, and mission of the organisations.

- Developing programmes to give greater emphasis on increasing school leaders' awareness of what constitutes empowering leadership behaviours and how their empowering behaviours may affect teachers' psychological empowerment and teachers' work outcomes.

- $\quad$ Participative decision making should be encouraged, and the leader should create an open atmosphere so that everybody becomes involved in discussions, and a healthy atmosphere leads to the increased morale of fellow teachers to work hard for attaining the department goals. Therefore, they would be advised to adapt participative management techniques and programmes aimed at increasing teachers' participation. This can provide an alternative to a traditional bureaucratic structure with a top-down approach to decision-making.

- Teacher empowerment strategies should be highly contextualised. Policy makers and educational administrators can empower teachers through providing holistic support, focusing on establishing ongoing communication and collaboration in schools, aligning the goals of school restructuring with teacher empowerment. 
- The effort to create and align schools' goals with teachers' personal goals should become the priority for school administrators.

- $\quad$ To achieve high work engagement, organisations first need to develop cultural contexts and practices for shaping a collaborative culture. Possible interventions could include structured leadership programmes that encompass behaviours, competencies, and attitudes needed to develop a good leader. The organisation could focus on other leadership development methods such as mentoring and coaching. It is vital for managers to fully understand what the indirect effects of instructional leadership on work engagement through psychological empowerment and school culture mean, in order for them to develop interventions to promote such behaviours. One possible intervention could be to create awareness and knowledge of the constructs as well as evidence-based interventions linked to the findings.

This study also has several limitations. First, because the data in this study were cross-sectional and not longitudinal in nature, some causal relationships could only be inferred, rather than empirically supported. Longitudinal and experimental studies need to be considered to give more definite conclusion about the causal effects between each variable. Second, the survey was given only to teachers in elementary schools, so the generalisation of high schools must be made carefully.

\section{References}

Bandura, A. (1969). Social-learning theory of identificatory processes. In D. A. Goslin (Ed.), Handbook of socialization theory and research (pp. 213-262). Chicago, IL: Rand McNally \& Company. Bedarkar, M., \& Pandita, D. (2014). A study on the drivers of employee engagement impacting employee performance. Procedia-Social and Behavioural Sciences, 133, 106-115.

Bulach, C. R. (2001). A 4-step process for identifying and reshaping school culture. Principal leadership, 1(8), 48-51.

Carasco-Saul, M., Kim, W., \& Kim, T. (2014). Leadership and employee engagement proposing research agendas through a review of literature. Human Resource Development Review, 14(1), 38-63. doi:1534484314560406.

Dastmalchian, A., Javidan, M., \& Alam, K. (2001). Effective leadership and culture in Iran: An empirical study. Applied Psychology, 5o(4), 532-558. doi:10.1111/1464-0597.00072

Deal, T. E., \& Peterson, K. D. (1999). Shaping school culture: The heart of leadership. San Francisco, CA: Jossey-Bass Publishers.

Dee, Jay R., Henkin A. B., \& Lee Duemer (2003). Structural antecedents and psychological correlates 
of teacher empowerment. Journal of Educational Administration, 41(3), 257-277.

DuPont, J. P. (2009). Teacher perceptions of the influence of principal instructional leadership on school culture: A case study of the American embassy school in New Delhi, India (Doctoral Dissertation).

Minneapolis, MN: University of Minnesota.

Gagné, M., Senecal, C. B., \& Koestner, R. (1997). Proximal job characteristics, feelings of empowerment, and intrinsic motivation: a multidimensional model1. Journal of Applied Social Psychology, 27(14), 1222-1240.

Gordon, G. (2013). School leadership linked to engagement and student achievement. Washington, DC: Gallup.

Gruenert, S. (2005). Correlations of collaborative school cultures with student achievement. Nassp

Bulletin, 89(645), 43-55.

Hackman, J. R., \& Oldham, G. R. (1975). Development of the job diagnostic survey. Journal of Applied Psychology, 60(2), 159-170.

Hair, J. F., Black, W. C., Babin, B. J., Anderson, R. E., \& Tatham, R. L. (2006). Multivariate data analysis (6th ed.). Upper Saddle River, NJ: Prentice Hall.

Halliger, P., \& Heck, R. H. (1998). Exploring the principals' contributions to school effectiveness: 1980-1995. School Effectiveness and School Improvement, 9(2), 157-191.

Hallinger, P. (2010). A review of three decades of doctoral studies using the Principal Instructional Management Rating Scale: A lens on methodological progress in educational leadership and management. Educational Administration Quarterly, 47(2), 271-306.

Hallinger, P., \& Heck, R. H. (1996). Reassessing the principal's role in school effectiveness: A review of empirical research, 1980-1995. Educational Administration Quarterly, 32(1), 5-44.

Hallinger, P., \& Huber, S. (2012). School leadership that makes a difference: International perspectives. School Effectiveness and School Improvement: An International Journal of Research, Policy and Practice, 1-9. doi:10.1080/09243453.2012.681508

Hallinger, P., \& Wang, W. C. (2015). Assessing instructional leadership with the principal instructional management rating scale. Heidelberg: Springer.

Jose, G., \& Mampilly, S. R. (2014). Psychological empowerment as a predictor of employee engagement: An empirical attestation. Global Business Review, 15(1), 93-104.

Kline, R. B. (2011). Principles and practice of structural equation modelling. New York, NY: Guilford publications.

Krejcie, R. V., \& Morgan, D. W. (1970). Determining sample size for research activities. Educational and Psychological Measurement, 30(3), 607-610.

Lakomski, G. (2001). Organizational change, leadership and learning: Culture as cognitive process. International Journal of Educational Management, 15(2), 68-77.

Le Clear, E. A. (2005). Relationships among leadership styles, school culture, and student achievement (Doctoral dissertation). Gainesville, FL: University of Florida.

Lee, A. N., \& Nie, Y. (2014). Understanding teacher empowerment: Teachers' perceptions of principal's and immediate supervisor's empowering behaviours, psychological empowerment and 
work-related outcomes. Teaching and Teacher Education, 41, 67-79.

Leonard, P. (1999). Understanding the dimensions of school culture: Value orientations ad value conflicts. Journal of Educational Administration and Foundations, 13(2), 27-53.

MacNeil, A. J., Prater, D. L., \& Busch, S. (2009). The effects of school culture ad climate on student achievement. International Journal of Leadership and Education, 12(1), 73-84.

Maxfield, C., \& Flumerfelt, S. (2009). The empowering principal: Leadership behaviours needed by effective principals as identified by emerging leaders and principals. International Journal of Teacher Leadership, 2(2), 39-48.

Mayrowetz, D., \& Smylie, M. A. (2004). Work redesign that works for teachers. Yearbook of the National Society for the Study of Education, 103(1), 274-302.

Mortimore, P. (2001). Globalization, effectiveness and improvement. School Effectiveness and School Improvement, 12(2), 229-249.

Noora, A. (2008). Iranian undergraduate non-English majors' language learning preferences. GEMA

Online Journal of Language Studies, 8(2), 33-44.

Nunnally, J. C. (1978). Psychometric theory (2nd ed.). New York, NY: McGraw-Hill.

Pavlova, E. (2013). Predicting employee engagement and job satisfaction among cabin crew (Master's thesis). Aalborg East: Aalborg University.

Peterson, K. D., \& Deal, T. (2009). The shaping school culture field book. New York, NY: Willey. Piccolo, R. F., Greenbaum, R. L., \& Eissa, G. (2012). Ethical leadership and core job characteristics: Designing jobs for employee well-being. In Work and quality of life (pp. 291-305). Dordrecht: Springer. Piccolo, R. F., \& Colquitt, J. A. (2006). Transformational leadership and job behaviours: The mediating role of core job characteristics. Academy of Management Journal, 49(2), 327-340. Purvanova, R. K., Bono, J. E., \& Dzieweczynski, J. (2006). Transformational leadership, job characteristics, and organizational citizenship performance. Human Performance, 19(1), 1-22. Quiñones, M., Van den Broeck, A., \& De Witte, H. (2013). Do job resources affect work engagement via psychological empowerment? A mediation analysis. Revista de Psicología Del Trabajo y de las Organizaciones, 29(3), 127-134.

Rinehart, J. S., Short, P. M., Short, R. J., \& Eckley, M. (1998). Teacher empowerment and principal leadership: Understanding the influence process. Educational Administration Quarterly, 34(1), 630-649. Salancik, G. R., \& Pfeffer, J. (1978). A social information processing approach to job attitudes and task design. Administrative Science Quarterly, 23, 224-253.

Schaufeli, W. B., \& Bakker, A. B. (2003). Utrecht work engagement scale: Preliminary manual. Utrecht: Utrecht University.

Schaufeli, W. B., Salanova, M., Gonzalez-Roma, V., \& Bakker, A. B. (2002). The measurement of burnout and engagement: A two sample confirmatory factor analytic approach. Journal of Happiness Studies, 3(1), 71-92.

Schein, E. H. (2004). Organizational culture and leadership (3rd ed.). San Francisco, CA: Jossey-Bass. Sergiovanni, T. J. (2006). The principalship: A reflective practice perspective. New York, NY: Pearson Education. 
Shuck, B., \& Mogan Herd, A. (2012). Employee engagement and leadership: Exploring the convergence of two frameworks and implications for leadership development in HRD. Human Resource Development Review, 11(2), 156-181.

Spreitzer, G. M. (1995). Psychological empowerment in the workplace: Dimensions, measurement, and validation. The Academy of Management Journal, 38(5), 1442-1465.

Thomas, K. W., \& Velthouse, B. A. (1990). Cognitive elements of empowerment: An "interpretive" model of intrinsic task motivation. Academy of Management Review, 15(4), 666-681.

Valentine, J. (2006). A collaborative culture for school improvement: Significance, definition, and measurement. Research Summary. Columbia, MO: University of Missouri.

Welch, M. (2011). The evolution of the employee engagement concept: Communication implications. Corporate Communications: An International Journal, 16(4), 328-346.

Wiley, J. W. (2010). The impact of effective leadership on employee engagement. Employment Relations Today, 37(2), 47-52.

$\mathrm{Xu}$, J., \& Cooper Thomas, H. (2011). How can leaders achieve high employee engagement? Leadership \& Organization Development Journal, 32(4), 399-416.

\section{Biographical note}

Adel Zahed-Babelan, PhD, is an Associate Professor at the Education and Psychology Department at the University of Mohaghegh Ardabili, Ardabil, Iran. His research interests focus on Educational Administration.

Ghodratollah Koulaei is a Doctoral Student of Educational Administration at the Education and Psychology Department at the University of Mohaghegh Ardabili, Ardabil, Iran. His research interests focus on Educational Administration and Educational Sciences.

Mahdi Moeinikia, PhD, is an Assistant Professor at the Education and Psychology Department at the University of Mohaghegh Ardabili, Ardabil, Iran. His research interests focus on Distance and E-Learning Planning.

Ali Rezaei Sharif, PhD, is an Assistant Professor at the Education \& Psychology Department at the University of Mohaghegh Ardabili, Ardabil, Iran. His research interests focus on Educational Psychology and School Psychology. 